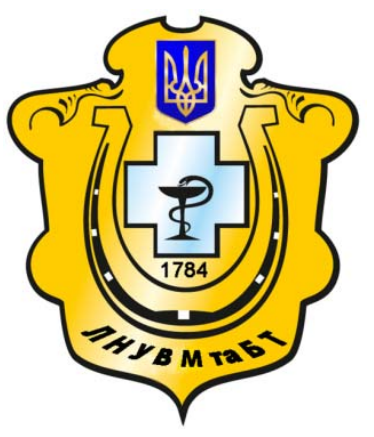

Науковий вісник Львівського національного університету ветеринарної медицини та біотехнологій імені С.3. Гжицького

Scientific Messenger of Lviv National University of Veterinary Medicine and Biotechnologies named after S.Z. Gzhytskyj

doi:10.15421/nvlvet6911

ISSN 2413-5550 print

ISSN 2518-1327 online

http://nvlvet.com.ua/

УДК 330.43:330.142

\title{
Економетричне моделювання впливу власного та позикового капіталу на збільшення доходу від реалізації продукції
}

\author{
B.I. Слейко ${ }^{1}$ О.В. Кіндрат ${ }^{2}$ \\ olenakind@ukr.net \\ ${ }^{1}$ Львівський торговельно-економічний університет, \\ вул. ТуганБарановського, 10, Львів, 79005, Україна; \\ ${ }^{2}$ Львівський національний університет ветеринарної медицини та біотехнологій імені С.3. Гэжицького, \\ вул. Пекарська, 50, м. Львів, 79010, Україна
}

\begin{abstract}
Діяльність підприємства в умовах ринкової економіки будьякої форми власності, організачійноправового статусу $і$ галузевої спрямованості безпосередньо залежить від джерел формування капіталу, їх співвідношення та ефективності використання. Завданням успішного розвитку підприємств виступає якісне управління їх капіталом. При цьвому обгрунтування його оптимальної величини відповідно до обсягу, структури $і$ змісту виробничої діяльності, вибір рачіонального способу його нарощування, урахування вартості і ризиків забезпечує стійкий розвиток підприємства.

У статті розглядається актуальна на сьогодні проблема вивчення залежності отриманого доходу від реалізації продукиії від власного та залученого капіталу. Під час залучення позикового капіталу підприємству необхідно визначити свій фінансовий стан та оиінити, наскільки вплинуть позикові кочти на результат його діяльності.

За даними експертів через відсутність налагодженої системи управління капіталом підприємства щьорічно втрачають не менше $10 \%$ своїх доходів недоотримання повної і оперативної фінансової інформації приводить до помилкових управлінських рімень. У сучасних умовах невизначеності і ризику вказані проблеми набувають особливої актуальності. Для їх вирішення необхідна постановка ефективного механізму фінансового менеджменту на підприємстві інструменту підвищення ефективності і керованості підприємства, поліпшення фінансовоекономічних результатів його діяльності.

Застосування традиційних методик обмежує можливості здійснення комплексної діагностики капіталу. Відповідно виникає необхідність в моделюванні нового системного підходу до діагностики капіталу, який має стати фундаментальною платформою менеджменту будьяких підприємств.

У статті здійснено економетричний аналіз фінансовоекономічних результатів діяльності одного із підприємств Львівської області, побудовано найпростіші моделі трендів, а також лінійні моделі регресії залежності обсягів діяльності базового підприємства від сум власного і позикового капіталу та оборотних активів, спрогнозовано обсяги отриманого доходу від реалізаиії продукиії аналізованого підприємства на найближчу перспективу. На основі проведеного аналізу впливу структури капіталу на фінансовоекономічні результати діяльності підприємства виявлено, шоо співвідношення позичкового $і$ власного капіталу є одним з головних чинників, що дозволяє максимізувати результати діяльності підприємства.

Ключові слова: економетричний аналіз, прогнозування, лінійний тренд, параболічний тренд, лінійні моделі регресії, власний капітал, позиковий капітал.
\end{abstract}

\section{Эконометрическое моделирование влияния собственного и заемного капи- тала на увеличение доходов от реализации продукции}

\author{
В.И. Елейко ${ }^{1}$, Е.В. Киндрат ${ }^{2}$ \\ olenakind@ukr.net \\ ${ }^{1}$ Львовский торговоэкономический университет, \\ ул. ТуганБарановского, 10, Львов, 79005, Украина;
}

Citation:

Yeleyko, V.I., Kindrat, O.V. (2016). Econometric modeling of the impact of equity and loan capital to increase income from sales. Scientific Messenger LNUVMBT named after S.Z. Gzhytskyj, 18, 2(69), 62-66. 
${ }^{2}$ Львовский национальный университет ветеринарной медицины и биотехнологий имени С.3. Гэицкого, ул. Пекарская, 50, г. Львов, 79010, Украина

Деятельность предприятия в условиях рыночной экономики любой формы собственности, организачионноправового статуса и отраслевой направленности напрямую зависит от источников формирования капитала, их соотношение и эффективности использования. Задачей успешного развития предприятий выступает качественное управления их капиталом. При этом обоснование оптимальной величины в соответствии с объемом, структурой и содержсанием производственной деятельности, выбор рационального способа его наращивания, учет стоимости и рисков обеспечивает устойчивое развитие предприятия.

В статье рассматривается актуальная сегодня проблема изучения зависимости полученного дохода от реализации продукции от собственного и привлеченного капитала.

При привлечении заемного капитала предприятию необходимо определить свое финансовое состояние и оценить, насколько повлияют заемные средства на результат его деятельности.

По данным экспертов из-за отсутствия отлаженной системы управления капиталом предприятия ежегодно теряют не менее $10 \%$ своих доходов недополучение полной и оперативной финансовой информации приводит к ошибочным управленческим решениям. В современных условиях неопределенности и риска указанные проблемы приобретают особую актуальность. Для их решения необходима постановка эффективного механизма финансового менеджмента на предприятии инструмента повышения эффективности и управляемости предприятия, улучшения финансовоэкономических результатов его деятельности.

Применение традиционных методик ограничивает возможности осуществления комплексной диагностики капитала. Соответственно, возникает необходимость в моделировании нового системного подхода к диагностике капитала, который должен стать фундаментальной платформой менеджмента любых предприятий.

В статье осуществлено эконометрический анализ финансовоэкономических результатов деятельности одного из предприятий Львовской области, построено простейшие модели трендов, а также линейные модели регрессии зависимости объемов деятельности базового предприятия от суми собственного и заемного капитала и оборотных активов, спрогнозировано объемы полученного дохода от реализации продукции анализируемого предприятия на ближсайшую перспективу. На основе проведенного анализа влияния структуры капитала на финансовоэкономические результаты деятельности предприятия выявлено, что соотношение ссудного и собственного капитала является одним из главных факторов, что позволяет максимизировать результаты деятельности предприятия.

Ключевые слова: эконометрический анализ, прогнозирование, линейный тренд, параболический тренд, линейные модели регрессии, собственный капитал, заемный капитал.

\title{
Econometric modeling of the impact of equity and loan capital to increase income from sales
}

\author{
V.I. Yeleyko ${ }^{1}$, O.V. Kindrat ${ }^{2}$ \\ olenakind@ukr.net \\ ${ }^{I}$ Lviv University of Trade and Economics \\ TuganBaranovsky Str., 10, Lviv, 79005, Ukraine; \\ ${ }^{2}$ Lviv National University of Veterinary Medicine and Biotechnologies named after S.Z. Gzhytskyi, \\ Pekarska Str., 50, Lviv, 79010, Ukraine
}

Activity of the enterprise in a market economy any form of ownership, organizational and legal status and aspiration branch directly depends on the sources of capital, their ratio and efficiency of use. The task of successful development of enterprises is the quality control of their capital. In this study the optimum value in accordance with the scope, structure and content production activities, the choice of rational method of building, cost and risks contributes to sustainable development of the enterprise.

In the article the actual present problem of the dependence of the income from sales of equity and loan capital is studying.

While attracting debt capital the enterprise needs to determine its financial condition and assess how loan funds affect the outcome of its activities.

According to the experts due to the lack of an established system of capital management enterprises annually lose at least $10 \%$ of their income a shortfall complete and operational financial information leads to wrong management decisions. In modern conditions of uncertainty and risk these problems are of particular relevance. For their solution requires setting an effective mechanism of financial management in the enterprise a tool to improve efficiency and manageability of enterprise, improve the financial and economic results of its activities.

The use of traditional methods limits the ability of a comprehensive diagnostic of capital. Accordingly, there is a need for modelling a new system approach to the diagnosis of capital, which must become the fundamental platform of management of any enterprise. Done econometric analysis of financial and economic performance of one of the enterprises of Lviv region, built a simple model of trends and linear regression model depending on the volume of basic enterprise of the amount of equity and debt and current assets, predicted volumes of the revenue from sales of the test enterprise on the short perspective.

On the basis of the analysis of the impact of capital structure on the financial and economic results of the company revealed that the ratio of loan and equity capital is one of the main factors to maximize the results of the company.

Key words: econometric analysis, forecasting, linear trend model, parabolic trend model, linear regression model, equity capital, loan capital. 


\section{Вступ}

У сучасних складних економічно нестабільних умовах, в яких змушені здійснювати свою діяльність підприємства України, питання пошуку напрямів оптимізації їх діяльності $\epsilon$ одним із пріоритетних завдань їхнього стратегічного розвитку. На даний час в Україні майже 40\% підприємств є збитковими.

На даному етапі економічних перетворень в Україні одним із головних завдань у сфері регулювання діяльності будьякого підприємства $\epsilon$ синхронізація економічної політики щодо залучення додаткових коштів на здійснення господарської діяльності. Українські підприємства все більше користуються залученими коштами, зокрема довгостроковими та короткостроковими банківськими кредитами. Керівництво підприємства намагається спрогнозувати ту чи іншу ситуацію, передбачити майбутні значення економічних показників, визначити наскільки ефективним та прибутковим буде залучення позикових коштів (Semenov and Peleshko, 2010). Вирішення цієї проблеми в умовах перехідної економіки, об'єктивно потребує системного підходу до економетричних досліджень і прогнозування 3 метою підвищення вірогідності їхніх результатів і надання дієвих рекомендацій менеджменту.

Meта cmammi. Здійснити економетричний аналіз діяльності досліджуваного підприємства, спрогнозувати залежність отримання доходу від реалізації продукції від власного та позикового капіталу. Дослідити, як оборотні активи впливають на збільшення доходу від реалізації продукції.

\section{Результати та їх обговорення}

У даній праці ми зосередили свої дослідження на економетричному аналізі капіталу підприємства (Eliseeva et al., 2005; Yeleyko et al., 2011). На основі даних про фінансову діяльність ПрАТ «Картоннопаперова компанія», представлених у табл. 1, використовуючи методику (Yeleyko et al., 2011), були побудовані лінійні моделі регресії залежності доходу від реалізації продукції ПрАТ «Картоннопаперова компанія» від власного і позикового капіталу та оборотних активів. Всі обчислення були одержані за допомогою пакету прикладних програм «STATGRAPHICS».

Таблиияя 1

Динаміка показників фінансової діяльності ПрАТ «Картоннопаперова компанія» за 20052015 рр., млн. грн.*

\begin{tabular}{|c|c|c|c|c|}
\hline Рік & $\mathrm{X}_{1}$ & $\mathrm{X}_{2}$ & $\mathrm{X}_{3}$ & $\mathrm{X}_{4}$ \\
\hline 2005 & 15,539 & 5,021 & 12,549 & 23,423 \\
\hline 2006 & 17,324 & 7,864 & 14,567 & 32,366 \\
\hline 2007 & 16,298 & 12,251 & 18,147 & 37,546 \\
\hline 2008 & 16,732 & 17,961 & 21,491 & 80,008 \\
\hline 2009 & 15,416 & 28,062 & 30,636 & 102,900 \\
\hline 2010 & 15,516 & 24,969 & 28,030 & 136,779 \\
\hline 2011 & 21,327 & 22,303 & 22,791 & 146,817 \\
\hline 2013 & 53,522 & 30,786 & 27,169 & \\
\hline 2014 & 53,512 & 27,311 & 20,079 & \\
\hline 2015 & 52,558 & 32,289 & 23,562 & 156,135 \\
\hline
\end{tabular}

*побудовано на основі даних, наданих підприємством

де, $\mathrm{X}_{1}$ власний капітал ПрАТ «Картоннопаперова компанія», в млн. грн.;

$\mathrm{X}_{2}$ оборотні активи ПрАТ «Картоннопаперова компанія», в млн. грн.;

$\mathrm{X}_{3}$ позичений капітал ПрАТ «Картоннопаперова компанія», в млн. грн.;

$\mathrm{X}_{4}$ дохід (виручка) від реалізації ПрАТ «Картоннопаперова компанія», в млн грн.

Лінійна хлн, параболічна х̃пр і експоненціальна хехр моделі трендів мають вигляд:

$$
\begin{aligned}
& \tilde{\mathrm{x}} 1 л н \text { н } 1,558+4,76662 \cdot \mathrm{t} \\
& \tilde{\mathrm{x}} 1 п \mathrm{p}=21,76885,33876 \cdot \mathrm{t}+0,91867 \cdot \mathrm{t} 2 \\
& \tilde{\mathrm{x}} 1 \exp =\exp \{2,31492+0,15480 \cdot \mathrm{t}\} \\
& \tilde{\mathrm{x}} 2 \text { лн }=4,7434+2,93424 \cdot \mathrm{t} \\
& \tilde{x} 2 \Pi p=2,068522+6,34019 \cdot t \quad 0,30963 \cdot t 2 \\
& \tilde{\mathrm{x}} 2 \exp =\exp \{1,8734+0,18548 \cdot \mathrm{t}\}
\end{aligned}
$$

$$
\begin{aligned}
& \widetilde{\mathrm{X} 3 л н}=15,7653+1,11579 \cdot \mathrm{t} \\
& \tilde{\mathrm{x} 3 п р}=5,19293+6,40195 \cdot \mathrm{t} \quad 0,48056 \cdot \mathrm{t} 2 \\
& \tilde{x} 3 \exp =\exp \{2,71772+0,06074 \cdot \mathrm{t}\} \\
& \tilde{\mathrm{x}} 4 \text { лн }=2,74207+16,1166 \cdot \mathrm{t} \\
& \widetilde{\mathrm{x}} 4 \text { пр }=13,7803+24,3778 \cdot \mathrm{t} \quad 0,75102 \cdot \mathrm{t} 2 \\
& \tilde{x} 4 \exp =\exp \{3,11949+0,21953 \bullet t\}
\end{aligned}
$$

де хілн, ххіпр , хіехр (i=1,2,3,4) усереднені значення досліджуваних показників фінансової діяльності ПрАТ «Картоннопаперова компанія»,

t час.

На основі одержаних рівнянь трендів (1) (12) були обчислені прогнозні значення та їх статистичні оцінки для досліджуваних показників фінансової діяльності ПрАТ «Картоннопаперова компанія», які представлені у табл. 2. 
Прогнозні значення та їх оцінки показників фінансової діяльності ПрАТ «Картоннопаперова компанія», млн грн

\begin{tabular}{|c|c|c|c|c|c|}
\hline \multirow[t]{2}{*}{ Показник } & \multicolumn{3}{|c|}{ Прогноз показника } & \multirow[t]{2}{*}{$\mathrm{ME}$} & \multirow[t]{2}{*}{ MSE } \\
\hline & на 2016 рік & на 2017 рік & на 2018 рік & & \\
\hline$\tilde{x}_{1}{ }^{\text {лн }}$ & 53,991 & 58,757 & 63,524 & 0 & 32,2262 \\
\hline$\tilde{\mathrm{x}}_{1}{ }^{\text {пр }}$ & 74,201 & 89,992 & 107,620 & 0 & 47,6653 \\
\hline$\tilde{x}_{1}{ }^{\exp }$ & 55,572 & 64,876 & 75,737 & 1,6408 & 78,1923 \\
\hline$\tilde{\mathrm{X}}_{2}{ }^{\mathrm{JH}}$ & 37,020 & 39,954 & 42,888 & 0 & 13,3578 \\
\hline$\tilde{x}_{2}{ }^{\text {пр }}$ & 30,208 & 29,427 & 28,026 & 0 & 8,2958 \\
\hline$\tilde{X}_{2}{ }^{\exp }$ & 50,085 & 60,292 & 72,580 & 0,1518 & 33,6913 \\
\hline$\tilde{\mathrm{x}}_{3}{ }^{\text {Лн }}$ & 28,039 & 29,155 & 30,270 & 0 & 6,1284 \\
\hline$\tilde{\mathbf{X}}_{3}{ }^{\text {пр }}$ & 17,467 & 12,816 & 7,204 & 0 & 7,9349 \\
\hline$\tilde{x}_{3}{ }^{\exp }$ & 29,542 & 31,392 & 33,358 & 0,4259 & 22,6453 \\
\hline$\tilde{\mathrm{x}}_{4}{ }^{\mathrm{IH}}$ & 180,025 & 196,142 & 212,258 & 0 & 190,708 \\
\hline$\tilde{\mathrm{x}}_{4}{ }^{\text {пр }}$ & 163,503 & 170,607 & 176,209 & 0 & 160,927 \\
\hline$\tilde{\mathrm{X}}_{4}{ }^{\exp }$ & 253,233 & 315,399 & 392,826 & 0,2870 & 676,025 \\
\hline
\end{tabular}

тут, ME середнє значення помилки,

MSE середньоквадратичне значення помилки.

Необхідно відзначити, що чим ближчими до нуля $є$ помилки ME і MSE, тим кращими чи вірогіднішими є одержані прогнозні значення показників фінансової діяльності ПрАТ «Картоннопаперова компанія».

Прогноз власного капіталу ПрАТ «Картоннопаперова компанія» х1 3 найменшою помилкою одержуємо на основі лінійного рівняння тренду (1):

$\tilde{\mathrm{x}} 1,2014$ лн, прогн $=53,991 \mathrm{млн.} \mathrm{грн.}$

$\widetilde{\mathrm{X}} 1,2015 л н$, прогн $=58,757$ млн. грн.

х1, 2016лн, прогн $=63,524$ млн. грн.

Прогноз з найменшою помилкою для оборотних активів ПрАТ «Картоннопаперова компанія» х2 отримуємо за допомогою параболічного тренду (5):

Х2,2014пр, прогн $=30,208$ млн. грн.

$\widetilde{\mathrm{x}} 2,2015 п$,прогн $=29,427$ млн. грн.

$\widetilde{\mathrm{x}} 2,2016 п$ прогн $=28,026$ млн. грн.

Прогноз 3 найменшою помилкою позикового капіталу ПрАТ «Картоннопаперова компанія» х3 одержуємо на основі лінійного тренду (7):

$\tilde{\mathrm{x}} 3,2014$ лн, прогн $=28,039$ млн. грн.

$\widetilde{\mathrm{X}} 3,2015$ лн, прогн $=29,155$ млн. грн.

х3,2016лн, прогн $=30,270$ млн. грн.

Прогноз з найменшою помилкою доходу від реалізації продукції ПрАТ «Картоннопаперова компанія» $\mathrm{x} 4$ одержуємо за допомогою параболічного тренду (11):

х4,2014пр, прогн $=163,503$ млн. грн.

$\widetilde{\mathrm{X}} 4,2015 п$ р, прогн $=170,607$ млн. грн.

х4,2016пр, прогн $=176,209$ млн. грн.

Необхідно відзначити, що оскільки середньоквадратична помилка MSE прогнозу доходу від реалізації x4 $є$ практично такою, як і самі прогнозні значення х4, то похибка прогнозу доходу від реалізації ПрАТ «Картоннопаперова компанія» $\mathrm{x} 4$ може бути досить значною.

На основі даних таблиці 1 були також побудовані лінійні рівняння регресії залежності доходу від реалізації ПрАТ «Картоннопаперова компанія» $\mathrm{x}_{4}$ від впливу таких факторів: власного капіталу $\mathrm{x}_{1}$, оборотних активів $\mathrm{x}_{2}$ та позикового капіталу $\mathrm{x}_{3}$ :

$$
\begin{aligned}
\tilde{\mathrm{x}}_{4}=29,52272 & +2,22726 \cdot \mathrm{x}_{1} ; \\
\mathrm{R}^{2}=0,5945 ; & \mathrm{F}=11,73 ;
\end{aligned}
$$

$$
\begin{aligned}
& \tilde{\mathrm{X}}_{4}=5,42684+4,63613 \cdot \mathrm{x}_{2} \text {; } \\
& \mathrm{R}^{2}=0,7772 ; \quad \mathrm{F}=27,92 ; \\
& \begin{array}{c}
\tilde{\mathrm{X}}_{4}=21,88191+5,17144 \cdot \mathrm{x}_{3} ; \\
\mathrm{R}^{2}=0,3484 ;
\end{array} \quad \mathrm{F}=4,28 ; \\
& \tilde{x}_{4}=7,95218+0,96430 \cdot \mathrm{x}_{1}+3,47447 \cdot \mathrm{x}_{2} \text {; } \\
& \mathrm{R}^{2}=0,8399 ; \quad \mathrm{F}=18,36 ; \\
& \tilde{\mathrm{X}}_{4}=51,07821+1,96972 \cdot \mathrm{x}_{1}+4,00665 \cdot \mathrm{x}_{3} \text {; } \\
& \mathrm{R}^{2}=0,7957 ; \quad \mathrm{F}=13,63 ; \\
& \tilde{\mathrm{X}}_{4}=45,86746+6,991374 \cdot \mathrm{x}_{2} \quad 4,51348 \cdot \mathrm{x}_{3} \text {; } \\
& \mathrm{R}^{2}=0,8550 ; \quad \mathrm{F}=20,64 ; \\
& \tilde{\mathrm{X}}_{4}=44,22217+0,03646 \cdot \mathrm{x}_{1}+6,80100 \cdot \mathrm{x}_{2} 4,37711 \\
& \cdot \mathrm{x}_{3} \text {; } \\
& \mathrm{R}^{2}=0,8551 ; \quad \mathrm{F}=11,80 .
\end{aligned}
$$

Необхідно відзначити досить високу довіру чи вірогідність лінійних рівнянь регресії (14), (16) (19), оскільки відповідні значення коефіціснтів детермінації $\mathrm{R}^{2} є$ близькими до одиниці $\left(0,77<\mathrm{R}^{2}<\right.$ 0,86). Про це також свідчать достатньо великі значення F критерію Фішера.

Парне лінійне рівняння регресії (13) має середню вірогідність $\left(\mathrm{R}^{2}=0,5945\right)$ і невелику достовірність має регресійна модель (2), оскільки $\mathrm{R}^{2}=0,3484$.

Аналіз парних лінійних рівнянь регресії (13) (15) показує, що найбільший вплив, але 3 невеликою достовірністю $\left(\mathrm{R}^{2}=0,3484\right)$ на дохід від реалізації ПрАТ «Картоннопаперова компанія» $\mathrm{x}_{4}$ має позиковий капітал $\mathrm{x}_{3} \quad\left(\mathrm{~b}_{3}=5,17144\right)$ рівняння $(15)$, менший вплив на дохід від реалізації $\mathrm{x}_{4}$ мають оборотні активи $\mathrm{x}_{2}\left(\mathrm{~b}_{3}=4,63613\right)$ рівняння (14) і найменший вплив на дохід від реалізації $\mathrm{x}_{4}$ із середньою вірогідністю має власний капітал $\mathrm{x}_{1}\left(\mathrm{~b}_{1}=2,22726\right)$ рівняння (13).

Зокрема, при збільшенні власного капіталу $\mathrm{x}_{1}$ рівняння (13) на 1 млн. грн. очікується збільшення доходу від реалізації ПрАТ «Картоннопаперова компанія» $\mathrm{x}_{4}$ в середньому на 2,22726 млн. грн.; при збільшенні оборотних активів $\mathrm{x}_{2}$ рівняння (14) на 1 млн грн очікується збільшення доходу від реалізації ПрАТ «Картоннопаперова компанія» $\mathrm{x}_{4}$ в середньому на 4,63613 млн грн; при збільшенні позикового капіталу $\mathrm{x}_{3}$ рівняння (15) на 1 млн грн очікується збільшення доходу від реалізації ПрАТ «Картоннопаперова компанія» $\mathrm{x}_{4}$ в середньому на 5,17144 млн грн.

Множинне лінійне рівняння регресії (16) дає підставу стверджувати, що більший вплив на дохід 
від реалізації $\mathrm{x}_{4}$ мають оборотні активи $\mathrm{x}_{2}$, менший власний капітал $\mathrm{x}_{1}$. Зокрема, при збільшенні власного капіталу $\mathrm{x}_{1}$ на 1 млн грн i деякому постійному чи середньому значенні оборотних активів $\mathrm{x}_{2}$ очікується збільшення доходу від реалізації ПрАТ «Картоннопаперова компанія» $\mathrm{x}_{4}$ в середньому на 0,9643 млн грн; при збільшенні оборотних активів $\mathrm{x}_{2}$ на 1 млн грн і середньому чи постійному значенні власного капіталу $\mathrm{x}_{1}$ очікується збільшення доходу від реалізації ПрАТ «Картоннопаперова компанія» $\mathrm{x}_{4}$ в середньому на 3,47447 млн грн.

Аналіз лінійної моделі регресії (17) показує, що більший вплив на дохід від реалізації ПрАТ «Картоннопаперова компанія» $\mathrm{x}_{4}$ має позиковий капітал $\mathrm{x}_{3}\left(\mathrm{~b}_{3}\right.$ $=4,00665)$, менший власний капітал $\mathrm{x}_{1}\left(\mathrm{~b}_{1}=1,96972\right)$. Зокрема, при збільшенні власного капіталу $\mathrm{x}_{1}$ на 1 млн. грн. і середньому чи постійному значенні позикового капіталу $\mathrm{x}_{3}$ очікується збільшення доходу від реалізації аналізованого підприємства в середньому на 1,96972 млн грн при збільшенні позикового капіталу $\mathrm{x}_{3}$ на 1 млн грн і середньому чи постійному значенні власного капіталу $\mathrm{x}_{1}$ очікується збільшення доходу в середньому на 4,00665 млн грн.

Множинне лінійне рівняння регресії (18) дає підставу стверджувати, що більший вплив на дохід від реалізації ПрАТ «Картоннопаперова кампанія» $\mathrm{x}_{4}$ мають оборотні активи $\mathrm{x}_{2}\left(\mathrm{~b}_{2}=6,91374\right)$, менший від'ємний вплив позиковий капітал $\mathrm{x}_{3} \quad\left(\mathrm{~b}_{3}=\right.$ 4,51348). Зокрема, при збільшенні оборотних активів $\mathrm{x}_{2}$ на 1 млн. грн. і постійному чи середньому значенні позикового капіталу $\mathrm{x}_{3}$ очікується збільшення доходу від реалізації ПрАТ «Картоннопаперова компанія» $\mathrm{x}_{4}$ в середньому на 6,91374 млн грн; при збільшенні позикового капіталу $\mathrm{x}_{3}$ на 1 млн грн і середньому чи постійному значенні оборотних активів $\mathrm{x}_{2}$ очікується зменшення доходу в середньому на 4,51378 млн грн.

Аналіз лінійного багатофакторного рівняння регресії (19) показує, що найбільший позитивний вплив на дохід від реалізації ПрАТ «Картоннопаперова компанія» х4 мають оборотні активи х2 ( b2=6,801), найменший від'ємний вплив на дохід має позиковий капітал х3 ( b3 = 4,37711). Так, при збільшенні власного капіталу х1 на 1 млн грн і середньому чи постійному значеннях оборотних активів х2 та позикового капіталу х3 очікується збільшення доходу від реалізації ПрАТ «Картоннопаперова компанія» х4 в середньому на 0,03646 млн грн; при збільшенні обо- ротних активів х2 на 1 млн грн і середньому чи постійному значенні власного капіталу х1 і позикового капіталу х3 очікується збільшення доходу в середньому на 6,801 млн грн; при збільшенні позикового капіталу х3 на 1 млн грн і середньому чи постійному значенні власного капіталу х1 очікується зменшення доходу від реалізації ПрАТ «Картоннопаперова компанія» х4 в середньому на 4,37711 млн грн.

Необхідно відзначити, що оскільки обсяг вхідної вибірки (табл. 1) є невеликим (10 років), то економічна інтерпретація коефіцієнтів регресії рівняння (19) може мати похибку.

\section{Висновки}

Отже, аналізованому підприємству для збільшення доходу від реалізації продукції необхідно нарощувати власний капітал і збільшувати оборотні активи та менше вдаватися до залучення позикових коштів.

Будь-якому підприємству в умовах швидкоплинних мікро- i макроекономічних процесів потрібно використовувати різноманітні економетричні моделі на різних рівнях економічної діяльності для аналізу та прогнозування свого розвитку 3 метою прийняття оптимальних управлінських рішень.

\section{Бібліографічні посилання}

Eliseeva I.I., Kuryshev, S.V., Koscheeva, T.V. i dr. (2007). Econometryka [ucheb.]. M.: finansy i statystyka (in Russian).

Yeleyko, V.I., Kopych, I.M., Bodnar, R.J., Demchyshyn, M.J. (2011). Econometryka: [navch. posibn.]. Lviv: vydavn. Lvivskoi komerciinoi Akademii (in Ukrainian).

Kvasnyts'ka, P.C. (2005). Instrumentarii i metody optymizacii cilovoi struktury kapitalu. Ekonomist, 5, 7375 (in Ukrainian).

Semenov, H.A., Peleshko, A.V. (2010). Optimizacija struktury kapitalu kompanii. Derzhava ta rehiony. 4, 164169 (in Ukrainian).

Yeleyko, V.I., Bodnar, R.J., Demchyshyn, M.J. (2011). Econometrychnyi analiz dijalnosty pidpryemstva: navch. posibn. Ternopil: Vydavn. «Navch. knyga Bogdan» (in Ukrainian).

Стаття надійшла до редакиії 1.09.2016 